\title{
Bijdrage tot de codificatiegeschiedenis van ons strafrecht rond het begin van de negentiende eeuw: het ontwerp-lijfstraffelijk wetboek van $1804^{*}$
}

\author{
O. MOORMAN VAN KAPPEN
}

INLEIDING

Utque antehac flagitiis, ita tunc legibus laborabatur.

Tacitus ${ }^{1}$.

Anthony Ewoud Jan Modderman (1838-1885), één van onze grote negentiendeeeuwse juristen op het gebied van het strafrecht, die wel de 'vader' van ons huidige wetboek van strafrecht (1881, ingevoerd 1886) wordt genoemd ${ }^{2}$, karakteriseerde in zijn in 1863 verdedigde proefschrift De hervorming onzer strafwetgeving de op dat moment vigerende Nederlandse strafwetgeving met de volgende woorden:

Zoo zijn wij dan, na vijftigjarige beraadslagingen, in het bezit van eene strafwetgeving, stelselloos en vol ongerijmdheden, beantwoordend noch aan de eischen van wetenschap en praktijk, noch aan de behoeften der natie, noch aan de belangen van den staat, noch aan den toestand der beschaving. Van een afzigtelijk geheel, den menschenvriend tot aanstoot, den burger tot gevaar, den vaderlander tot beschaming, voor de regtsgeleerden een bron van voortdurenden strijd ${ }^{3}$.

Deze hartekreet van Modderman, die hem als het ware praedestineerde voor zijn latere lidmaatschap van de in 1870 ingestelde 'Staatscommissie voor de Zamenstelling van een Wetboek van Strafregt"4 , had betrekking op "de toenmalige strafwetgeving en op de vele sedert het herstel van onze nationale onafhankelijkheid in

* Als voordracht gehouden op het congres van het Nederlands Historisch Genootschap, 4 en 5 november 1977, Utrecht en Amersfoort.

1. Annales, III, 25.

2. Voor een beknopte levensschets vergelijk Nieuw Nederlandsch Biografisch Woordenboek (NNBW) (10 din., Leiden, 1911-1937; ongewijzigde herdruk met nieuw registerdeel Amsterdam, 1974) VIII, kol. 1158; A. G. Bosch, Het ontstaan van het Wetboek van Strafrecht. Aantekeningen over de werkzaamheden van de Staatscommissie, in 1870 belast met de samenstelling van een ontwerp van een nieuw Wetboek van Strafrecht art. 1-91 (dissertatie Leiden, Zwolle, 1965) 68-72 (met opgave van verdere bio- en bibliografische literatuur); W. P. J. Pompe, Geschiedenis der Nederlandse strafrechtswetenschap sinds de codificatiebeweging (Amsterdam, 1956) 287-297.

3. A. E. J. Modderman, De hervorming onzer strafwetgeving. Kritische beschouwing der wet van 29 juni 1854 (Staatsblad no. 102) - houdende eenige veranderingen in de straffen op misdrijven gesteld -, eerste gedeelte (dissertatie Leiden, 's-Gravenhage, 1863) 34-35. Vergelijk de karakteristiek'van A. de Pinto: 'de Code Pénal doet den Franschen wetgever zoo veel schande, als zijne burgerlijke wetten hem eer aandoen', Handleiding tot het Burgerlijk Wetboek, I (3e dr.; 's-Gravenhage, 1849) 14 , nt. 1 .

4. $\mathrm{KB}$ van 28 sept. 1870 Ino. 21 . 
1813 ondernomen pogingen om ter vervanging van de 'provisioneel' in december 1813 gehandhaafde Code pénal een nationaal strafwetboek te ontwerpen, pogingen die om uiteenlopende redenen mislukten ${ }^{5}$. Een nieuw geluid was het echter niet.

DE GEBREKEN VAN HET STRAFRECHT EN DE STRAFRECHTSPLEGING HIER TE LANDE IN DE ACHTTIENDE EEUW

Immers, als wij even afzien van de kortstondige periode van 1 februari 1809 tot 11 december 1813, gedurende welke achtereenvolgens het Crimineel Wetboek voor het koningrijk Holland en de Code pénal van 1810 van kracht waren ${ }^{6}$ en tijdens welke het weinig raadzaam was deze wetboeken publiekelijk te kritiseren, dan kan worden vastgesteld, dat rond het begin van de negentiende eeuw de kritiek op het toen vigerende straf- en strafprocesrecht bepaald niet voor Moddermans geciteerde invectieven onderdeed. Zo schreef in 1808 een anoniem scribent in de Schouwburg van in- en uitlandsche Letter-en Huishoudkunde:

'Wie kan het nuttig en behoorlijk achten ... dat in 't criminele dezelfde misdaden in

5. Vergelijk voor de provisionele handhaving van de Code pénal: Souverein Besluit van 11 december 1813, Staatsblad, no. 10. Bij dit besluit werden overigens wel enige niet onbelangrijke wijzigingen in de Code pénal aangebracht, voornamelijk op het stuk van het straffenstelsel en de straftoemetingsregels. Ook werd de jury afgeschaft. Vergelijk R. J. C. Cornegoor, 'Opmerkingen over de jury in Nederland tijdens de Franse inlijving', Tijdschrift voor rechtsgeschiedenis, XXIV (1956) 196-201. Voor een beknopt overzicht van de genoemde mislukte codificatiepogingen op het gebied van het strafrecht hier te lande: Bosch, Het ontstaan, 35-42; G. A. van Hamel, Inleiding tot de studie van het Nederlandsche Strafrecht (4e dr., bewerkt door J. V. van Dijck, Haarlem-'s-Gravenhage, 1927) 78-81.

6. In de bij het zogenaamde Haags Verdrag van 16 mei 1795 aan Frankrijk afgestane, voormalig'Staatse' gebiedsdelen (Staats-Vlaanderen, Staats-Opper-Gelre, Maastricht en de Staatse Landen van Overmaze) heeft het Crimineel wetboek uiteraard nooit gegolden; nog in dat zelfde jaar werd in deze alstoen bij Frankrijk ingelijfde gebieden de Franse wetgeving van toepassing. In de bij tractaat van 16 maart 1810 eerder dan de rest van het 'Koningrijk Holland' bij het Franse keizerrijk ingelijfde 'Hollandse' gebieden bezuiden de Waal - bij Sénatus-consulte van 24 april 1810 geconstitueerd tot de départements cisrhénans van de Bouches-de-l'Escaut en de Bouches-du-Rhin alsmede tot het arrondissement Breda, dat gevoegd werd bij het departement des Deux-Nèthes - werd de Code pénal van 1810 bij Décret impérial van 8 november 1810 met ingang van 1 januari 1811 ingevoerd (evenals trouwens de Code d'instruction criminelle); vergelijk C. J. Fortuyn, Verzameling van wetten, besluiten en andere regtsbronnen van Franschen oorsprong (3 dln.; Amsterdam, 1839-1841) I, 13-14. In de rest van het (voormalige) 'Koningrijk Holland' (benoorden de Waal), ingelijfd bij het keizerrijk bij Décret impérial van 9 juli 1810 , werd de Code de procédure criminelle ingevoerd bij Décret impérial van 18 oktober 1810 met ingang van 1 januari 1811 (art. 114), de 'nouveau Code criminel' -namelijk die van 1810-echter volgens Décret impérial van 25 november 1810 eerst op de dag van de installatie van elk cour impériale. Vergelijk Fortuyn, ${ }^{\mathrm{K}}$ Verzameling, I, 12,"67. Dat van"Den Haag werd op 1 maart 1811 geïnstalleerd, zodat eerst op die"datum de Code pénal voor het ressort van dit keizerlijk gerechtshof ging gelden. Vergelijk uitvoeriger $\mathbf{R}$. Feenstra, 'Enkele opmerkingen over de invoering der;'Franse wetgeving in Nederland (1810-1813)', Tijdschrift voor rechtsgeschiedenis, XX (1952) 344-351. 
twee naburige provinciën over en weer met dood- of minder straf gestraft werden, b.v. dat hij, die één of twee schapen gestolen had, in Holland gehangen werd, maar in Vriesland niet, terwijl enkele huisbraak in Holland doorgaans niet, maar in Vriesland aan de galg bragt; ja dat op dubbel overspel in eenige Hollandsche wetten doodstraf, in andere geldboete gesteld was? Wie kan zulk een regtspleging verdeedigen?

Zelfs als men in aanmerking neemt, dat in de eerste jaren van het 'Bataafse' tijdperk zulke felle kritiek veelal van unitaristisch gezinden afkomstig was en dat politieke motieven bij zulke kritieken veelal een hartig woordje meespraken ${ }^{8}$, zelfs dan moet worden toegegeven, dat de rond het begin van de negentiende eeuw hier te lande op strafrechtelijk gebied heersende toestanden bepaald niet minder discutabel, ja zelfs nog gebrekkiger en uit een oogpunt van rechtszekerheid en rechtsgelijkheid bepaald 'slechter' waren dan in 1863. Anno 1863 bestond er althans een landelijk geldende strafwetgeving, de 'vernederlandste' Code pénal, door tal van Nederlandse wetten gewijzigd en aangevuld ${ }^{9}$, en, sinds 1838 , een nationaal Wetboek van Strafvordering ${ }^{10}$, toegepast door een nationaal georganiseerde rechterlijke macht volgens uniforme regels van strafprocesrecht. Maar zelfs een zodanige eenheid van materieel en formeel strafrecht bestond begin negentiende eeuw nog niet.

Nog in de achttiende eeuw - die, zo zou men kunnen zeggen, voor wat het materiële strafrecht betrof voortduurde tot 1809 , voor wat het strafprocesrecht aanging tot $1811^{11}$ - werd het strafrecht uit een oogpunt van rechtsbedeling gekenmerkt door rechtsverscheidenheid en rechtsonzekerheid. Het eerste was op zichzelf niets bijzonders, zijnde het immers notoir, dat onder het ancien régime elke provincie in beginsel haar eigen recht kende. Daarbij zij aangetekend, dat die rechtsverscheidenheid zich niet beperkte tot verschillen tussen provinciën onderling. Ook binnen de provinciën zelf trof men naast het zogenaamde 'landsgemene' strafrecht een niet zelden aanzienlijke verscheidenheid van recht tussen de onderscheidene in-

7. Schouwburg van in- en uitlandsche Letter- en Huishoudkunde, IV (Den Haag, 1808) 346-348.

8. Voor een voorbeeld uit die jaren - de hartige kritiek op het toenmalige straf- en strafprocesrecht van de Gelderse jurist mr. H. H. Vitringa in de (eerste) constitutiecommissie van 1796, des te opmerkelijker omdat Vitringa een notoire 'federalist' was - vergelijk $O$. Moorman van Kappen, 'Uitwendige schets der wordingsgeschiedenis van het ontwerp-Lijfstraffelijk Wetboek 1804', Samenwinninge. Tien opstellen over rechtsgeschiedenis geschreven ter gelegenheid van het tienjarig bestaan van het interuniversitair instituut Nederlands Centrum voor Rechtshistorische Documentatie (Zwolle, 1977) 116-118.

9. Voor een beknopt overzicht vergelijk Van Hamel, Inleiding, 76-77.

10. Op 1 januari 1926 vervangen door het thans nog - zij het niet ongewijzigd - geldende Wetboek van Strafvordering, vastgesteld bij de wet van 15 januari 1921, S. 14.

11. Het in 1809 vastgestelde 'Wetboek op de regterlijke instellingen en regtspleging in het koningrijk Holland' werd ten gevolge van de spoedig daarop gevolgde inlijving bij Frankrijk niet meer ingevoerd. Vergelijk omtrent dit wetboek O. Moorman van Kappen, 'Een ongeschreven hoofdstuk uit de geschiedenis van onze rechterlijke organisatie', Opstellen rond het thema rechterlijke organisatie, bijeengebracht ter gelegenheid van het vijftigjarig bestaan van de faculteit der rechtsgeleerdheid van de Katholieke Universiteit Nïmegen (Deventer, 1974) 193-213. 
liggende rechtskringen aan, welke zich op strafrechtelijk gebied bepaald niet steeds beperkte tot ${ }^{\dagger}$ de boetstraffelijke zaken, de lichtere strafbare feiten, die men tegenwoordig 'overtredingen' zou noemen. Ook op het stuk van de lijfstraffelijke zaken, de zwaardere delicten (de 'misdaden' oftewel crimina), deed die verscheidenheid zich gevoelen, al bestonden er op dit punt duidelijke graduele verschillen tussen de provinciën ${ }^{12}$.

De genoemde rechtsonzekerheid sproot uit tweeërlei oorzaak voort. Voor zover het het 'geschreven' strafrecht betrof uit de veelal vage en weinig scherpe omschrijving der strafbare feiten in de wetgeving en de al even dikwijls even weinig scherp omschreven daartegen bedreigde straffen. Zo bepaalde het van 1721 daterende Landrecht van Tieler- en Bommelerwaarden: 'Die overspel of bloedschande begaan, zullen staan tot des Heeren Straffe' ${ }^{13}$. Niet alleen de strafmaat, maar ook de strafkeuze was nogal eens overgelaten aan het arbitrium iudicis. Daarenboven was vooral het materiële strafrecht, de aanwijzing der strafbare feiten en de daartegen bedreigde straffen betreffende, slechts ten dele in van de toenmalige overheden uitgegane plakkaten, ordonnantiën, keuren en beschreven costumen neergelegd. Ook op strafrechtelijk gebied bestond het nodige gewoonterecht, terwijl als subsidiaire rechtsbronnen in formele zin ${ }^{14}$ meestal fungeerden het Romeinse recht - in de eerste plaats de boeken 47 en 48 van de Digesten, de zogenaamde Libri terribiles -, de zo dadelijk te noemen zestiende-eeuwse Criminele Ordonnanties, brokjes canoniek en zelfs 'Mozaisch' - dus bijbels - recht en ten slotte de doctrines van gezaghebbende auteurs op het gebied van het criminele recht, zoals - still going strong Damhouder ${ }^{15}$ en Antonius Matthaeus (II) ${ }^{16}$.

Dat in het kader van een dergelijke constellatie de rechterlijke rechtsvinding in strafzaken nogal eens resulteerde in zeer divergerende en onderling contrariërende uitspraken en beslissingen in gelijksoortige zaken is niet zo verwonderlijk. Niet al-

12. Zo bestond er in Friesland op het stuk van de 'misdaden' een vrij grote mate van rechtseenheid sinds de totstandkoming van de Statuten, Ordonnantiën en Costumen van 1602 (heruitgegeven in 1723 en 1770). Aanvullend (subsidiair) gold het Romeinse recht. Deze rechtseenheid in criminalibus werd in hoge mate bevorderd door de concentratie van de rechtspraak inzake 'misdaden' bij het hof van Friesland. In Gelderland, waar het hof van Gelderland in de zeventiende en achttiende eeuw bemoeienis had met de totstandkoming van de zogenaamde 'gereformeerde' stad- en landrechten, waakte dit hof tegen een al te grote rechtsverscheidenheid op het gebied van het lijfstraffelijk recht. Vergelijk meer in het algemeen S. J. Fockema Andreae, De Nederlandse staat onder de Republiek (Verhandelingen der Koninklijke Nederlandse Akademie van Wetenschappen, afdeling letterkunde, nieuwe reeks LXVIII, iii; 2e dr. Amsterdam, 1962) 98-101.

13. Landregt van Thielre- en Bommelreweerden... (Arnhem, 1721) hfdst. xli, art. 3.

14. Dus in de zin van bronnen, waaruit algemeen in een bepaalde rechtskring verbindend recht voortvloeide.

15. J. Damhouder (1507-1581), Praxis rerum criminalium. . . (eerste editie Leuven, 1554; eerste Nederlandse bewerking Leuven, 1555).

16. Ant. Matthaeus (II) (1601-1654), De Criminibus, ad Libros 47 et 48 Digestorum commentarius ... (eerste editie Utrecht, 1644). 
leen konden de verba legis verschillend geïnterpreteerd worden - dat probleem bebestaat in de moderne rechtspraak trouwens in beginsel ook nog -, maar bij het stilzwijgen of duisterheid van het statutaire recht, het 'wettenrecht' dus (de beschreven costumen daaronder begrepen), begonnen de moeilijkheden eerst recht. Soms liet men dan het onbeschreven gewoonterecht praevaleren boven het Romeinse recht en eventuele andere subsidiaire rechtsbronnen ${ }^{17}$, soms ook week men in zo'n geval direct uit naar het 'gemene recht', het vrij algemeen subsidiair geldende Romeinse recht ${ }^{18}$. En in die gevallen, waarin men een beroep deed op de opinies der rechtsgeleerde schrijvers, was de situatie niet zelden deze, dat tegenstrijdige opvattingen aan de hand van verschillende schrijvers verdedigd konden worden ${ }^{19}$.

Trouwens, ook op het gebied van het strafprocesrecht heersten - afgezien nog van het hoe langer hoe meer controversiële instituut van de pijnbank (tortuur) praktijken, die begrijpelijkerwijze tot onvrede aanleiding gaven, zoáls de manier, waarop de baljuws en andere met de vervolging van strafzaken belaste officieren omsprongen met hun 'compositiebevoegdheid' (schikkingsbevoegdheid door afkoop van een strafvervolging), de omslachtige en gebrekkige wijze van procederen, het als maar verder oprukken van de sterk inquisitoriaal getinte zogenaamde extraordinaire strafprocedure ten koste van de ordinaire en - in het kielzog daarvan de sterk besnoeide mogelijkheid om door appelleren redres van in eerste instantie gewezen strafvonnissen te verkrijgen, doordat de regel confessus non appellat zulk een appelmogelijkheid afsneed ${ }^{20}$.

17. Een voorbeeld hiervan is te vinden in ibidem, Lib. XLVW, Dig., Tit. v, cap. vii, no. 4. Bij het stilzwijgen van het Utrechtse statutaire recht omtrent de al dan niet strafbaarheid van poging tot doodslag, acht hij niet het Romeinse recht - volgens hetwelk conatus caedis met de doodstraf werd bestraft - van toepassing, maar de daaraan derogerende generalis consuetudo et usus, dus het ongeschreven inheemse costumiere recht, volgens hetwelk poging tot doodslag alleen in zeer ernstige gevallen met de dood bestraft kon worden. Des te opmerkelijker is deze opvatting van Matthaeus nu de op 5 juli 1550 door Karel V als 'erfheere' van stad, steden en landen van Utrecht vastgestelde Costumen, Usantiën, Politiën ende Stijl van procederen der stad, jurisdictie ende vrijheyd van Utrecht - waarvan de artt. 40 en 43 handelden over respectievelijk doodslag en moord, daarbij inderdaad niets vermeldende over poging tot doodslag of moord - aan het slot onder meer bepaalden, 'dat men in allen saken ende stucken, niet begrepen ende verklaert in dese onse voorsz. ordonnantie, sal procederen en hem reguleren conforme en naer dispositie van 't geschreven recht', dat wil zeggen het Romeinse recht (J. v. d. Water, Groot Placaatboek ... van Utrecht, III (Utrecht, 1729) 363.

18. Vergelijk omtrent de subsidiaire gelding van het Romeinse recht in het algemeen: J. Ph. de Monté verLoren, Hoofdlijnen uit de ontwikkeling der rechterlijke organisatie in de Noordelijke Nederlanden tot de Bataafse omwenteling (5e dr. bewerkt door J. E. Spruit; Deventer, 1972) 211-212 en de aldaar genoemde literatuur.

19. Voor enige saillante voorbeelden ter illustratie van het voorgaande betoog vergelijke men J. A. Fruin, 'Het recht en de rechtsbedeeling onder de Republiek der Vereenigde Nederlanden', Verslagen en Mededeelingen der Vereeniging tot uitgaaf der bronnen van het Oude Vaderlandsche Recht, I ('s-Gravenhage, 1885) 392-394.

20. Vergelijk uitvoeriger: Fockema Andreae, Nederlandse Staat, 135-136; Fruin, 'Rechtsbedeeling Republiek', 398-404; W. Wedekind, 'Wielant et Damhouder et l'appel en matière criminelle. L'Adage confessus non appellat', Tijdschrift voor rechtsgeschiedenis, XLIV (1976) 153-158. 
Hoewel deze en andere moeilijk te loochenen gebreken van strafrecht en strafrechtspleging onder het ancien régime tegen en in de negentiende eeuw breed zijn uitgemeten, uiteraard vooral door voorstanders van de codificatie, moet anderzijds niet uit het oog worden verloren, dat er in de praktijk van de zeventiende- en achttiende-eeuwse strafrechtspleging ook wel degelijk willekeur-mitigerende en - prohiberende factoren werkzaam waren. Zo genoten - zeker onder bij de strafrechtspleging betrokken juristen - de in 1570 door Philips II uitgevaardigde zogenaamde Criminele Ordonnantiën ${ }^{21}$ groot gezag. De invoering ervan was weliswaar op zoveel moeilijkheden - in de eerste plaats strijd met de loffelijke en welhergebrachte costumen - gestuit, dat ze bij de pacificatie van Gent geschorst waren ${ }^{22}$, zodat er in later tijd in de meeste provinciën der Republiek geen eigenlijke wetskracht aan werd toegekend ${ }^{23}$, maar het gezag ervan was bepaald niet minder dan dat van veel geciteerde auteurs op het gebied van het strafrecht ${ }^{24}$. Minder gezag werd in het algemeen toegekend aan de hier te lande niet ingevoerde maar desondanks niet onbekende 'Caroline-ordonnantie'25.

In de tweede plaats dient in aanmerking genomen te worden, dat, zeker in de zeventiende en achttiende eeuw, de academisch, dus Romeinsrechtelijk geschoolde juristen een forse greep hadden op de strafrechtspleging. Niet alleen bemanden zij de provinciale hoven van justitie, maar ook - althans goeddeels - de grotere met

21. Respectievelijk die op de 'crimineele justitie' van 5 juli 1570 en die op de 'stijl van procedeeren in crimineele zaken' van 9 juli 1570. Tekstuitgave onder meer in A. S. de Blécourt en N. Japikse, Klein Plakkaatboek van Nederland (Groningen-Den Haag, 1919) 81-108. Vergelijk over deze ordonnantiën laatstelijk M. van de Vrugt, De Criminele Ordonnantiën van 1570. Enkele beschouwingen over de eerste strafrechtcodificatie in de Nederlanden (dissertatie Utrecht; Zutphen, 1978). 22. Vergelijk De Blécourt en Japikse, Klein Plakkaatboek, 114-115.

23. In Gelderland was de afkondiging ervan zelfs geschied 'onder expresse protestatie de non prejudicie der Land- en Stadrechten', bij het verdrag van Venlo (1543) gegarandeerd. Vergelijk W. A. van Spaen, Verhandeling over de Crimineele Ordonnantie van Koning Philips in Gelderland (Arnhem, 1794).

24. Voor wat Holland betrof, hield Bavius Voorda staande, dat de ordonnantiën in 1576 alleen maar geschorst waren 'voor zo verre zij ... eenigen godsdienstdwang ademden'. B. Voorda, De Crimineele Ordonnantiën van Koning Philips van Spanje... (Leiden, 1792) 6 vlg. van de geannecteerde Verhandeling over het verstand van de ordonnantie van Koning Philips... Ook Eduard van Zurck, Codex Batavus (4e dr. bewerkt door P. van der Schelling; Leiden, 1764) 266 in voce 'Delicten' (\$1) stelde, dat 'in de Nederlanden' volgens deze ordonnanties werd geprocedeerd, 'uitgezondert voor zo verre tegen der Landen recht, vrijheid en loflijke gewoonte en hervorming gestatueert is bij dezelve ordonnantie'. Andere Hollandse auteurs bestreden deze stelling echter. 25. De in 1532 op de rijksdag van Regensburg vastgestelde Peinliche Gerichtsordnung van keizer Karel V, Constitutio Criminalis Carolina. Tekstuitgave: Die Peinliche Gerichtsordnung Kaiser Karls $V$ von 1532 (uitgegeven door G. Radbruch, voltooid door A. Kaufmann; 4e dr., Stuttgart, 1975). De Carolina behelsde hoofdzakelijk bepalingen van strafprocesrecht; ze was bedoeld als een algemene subsidiaire straf(proces)wetgeving voor het Heilige Roomse Rijk. Ze vertoont een minder 'modern' karakter dan de speciaal voor de Nederlanden uitgevaardigde criminele ordonnantiën. Vergelijk omtrent de Carolina: H. Conrad, Deutsche Rechtsgeschichte (I, Karlsruhe, 1962; II, 1966) I, 448-450. 
criminele jurisdictie in eerste aanleg beklede rechterlijke colleges, zoals de schepenbanken van grotere steden en 'hoge banken' ten plattelande, zo niet als lid van het college dan toch wel als griffier. En voor zover dat niet het geval was, bijvoorbeeld in sommige hoge heerlijkheden, oefenden zij toch grote, veelal beslissende invloed uit op de rechterlijke beslissingen vanwege de wijd verbreide praktijk van het zogenaamde 'assumeren' of 'consulteren' van juristen ${ }^{26}$. Niet alleen hun aller Romanistisch-juridische vorming, die een geneigdheid tot het recipiëren van Romeins recht in de hand werkte, maar ook hun gemeenschappelijke 'vakliteratuur' werkte als het ware filtrerend ten aanzien van al te extreme opvattingen. Zelfs als en voor zover hun rol het verdedigen van een 'partijdig' standpunt met zich bracht - bijvoorbeeld als advocaat in een ordinaris strafprocedure - dan nog moest dat standpunt op een objectief verdedigbare wijze geargumenteerd verwoord worden en het zich kunnen beroepen op zoveel mogelijk gezaghebbende auteurs was alsdan geen overbodige luxe. Treffend is in elk geval, dat uit de door De Monté verLoren ondernomen analyse van in strafrechtelijke zeventiende- en achttiende-eeuwse verhandelingen frequent geciteerde werken een tamelijk algemeen verbreide kennis blijkt van een niet gering aantal telkens weer aangehaalde 'autoriteiten' ${ }^{\text {27. }}$

Dat zelfde onderzoek leidde De Monté verLoren overigens tot de conclusie - en ook dat was een al te arbitraire tendenzen matigende factor -, dat in die zeventiendeen achttiende-eeuwse, specifiek aan het strafrecht gewijde literatuur overwegend een gematigdheid doorklinkt, leidend tot een duidelijke 'afkeer van onnoodige strengheid en wreedheid' bij de strafrechtspleging ${ }^{28}$. Trouwens, ook met betrekking tot de praktijk van de strafrechtspleging in de beide genoemde eeuwen gewaagt Fockema Andreae van een 'heilzame matiging', teweeggebracht door het 'vaderlijke gezag' der magistraten n'en déplaise à enkele als causes célèbres bekend staande evidente ontsporingen, zoals het justitiële schrikbewind van een De Mepsche van Faan in het Groninger Westerkwartier ${ }^{29}$. De conclusie van de eerstgenoemde auteur

26. Vergelijk De Monté verLoren, Hoofdlijnen, 212-215.

27. Zie Idem, Geschiedenis van de wetenschap van het strafrecht en strafprocesrecht in de Noordelijke Nederlanden vóor de codificatie (Amsterdam, 1942) passim. Vrijwel steeds wordt Ant. Matthaeus' (II) De Criminibus geciteerd. Zeer veelvuldig aangehaalde schrijvers zijn onder meer Damhouder, Praxis rerum criminalium; S. van Leeuwen, Paratitula juris novissimi. Dat is: een kort begrip van het Rooms-Hollands reght... (1e dr., Leiden, 1652); Idem, Censura Forensis... (1e dr., Amsterdam, 1663); Idem, Proces crimineel. . . (1e dr., Leiden, 1677); J. Voet, Commentarius ad Pandectas... (1e dr., I, Leiden, 1698, II, Den Haag, 1704); P. Bort, 'Tractaet crimineel. ..', in: Alle de wercken begrepen in ses tractaten... (1e dr., Den Haag, 1681).

28. Zie De Monté verLoren, Geschiedenis Strafrechtswetenschap, 120. Onnodig op te merken, dat ook die 'gematigdheid' door terugblikkende twintigste-eeuwers gerelativeerd dient te worden. Zo gaapt hier te lande een brede kloof op het stuk van de waardering van lijfstraffen tussen de zeventiende en de achttiende eeuw enerzijds en de twintigste anderzijds.

29. Fockema Andreae, Nederlandse Staat, 135. Vergelijk voor een kort overzicht van het beruchte 'monsterproces' te Faan tegen tweeëntwintig van sodomie beschuldigden in 1731 : J. Frima, 
laat zich eenvoudiger verifiëren dan de stelling van de laatstgenoemde, welke door een grootschalig systematisch kwantitatief en kwalitatief onderzoek in de rechterlijke archieven zou dienen te worden geschraagd. En dat laatste is in wezen nog al te weinig geschied. Voor wat de bestraffing van landlopers uit den vreemde en andere niet tot de eigen ingezetenen behorende delinquenten met een zwervende levenswijze betrof, gaat die stelling ons inziens in elk geval niet p $^{30}$.

Een en ander betekende intussen niet, dat er in de loop van de achttiende eeuw niet ook onder de juristen, althans onder een deel van hen - aan kwantitatieve schattingen waag ik mij niet -, een steeds duidelijker onvrede rees met het bestaande straf-en strafprocesrecht, ook al waren het niet allemaal lieden als Willem Schorer (1717-1800), die poogde de vaderlandse gezapigheid met een soort schokeffect te doorbreken met zijn Vertoog over de ongerijmdheid van het samenstel onzer hedendaagsche regtsgeleerdheid en praktijk (Middelburg-Amsterdam, 1777). Zijn afschuw van de tortuur schildert hij in de schrilste bewoordingen:

I $\mathrm{k}$ beef die ramspoedige modderpoel van ongeregtigheid te roeren, dewijl al in den aanbeginne een natuur verkragtend wangedrogt, ten verderve bijwijlen van onschuldigen in de hel uitgebroeid en door een eerloos tyran uit dien heillozen zwavelkolk opgebaggert, zig aan mij opdoet: ik meen een vervloekte tortuur of pijnbank ${ }^{31}$.

Zeker in de achttiende eeuw vormden de pijnbank ${ }^{32}$, de rechtmatigheid van de doodstraf $^{33}$ en de veelal gebrekkig geregelde en nòg gebrekkiger gepraktiseerde extraordinaris-strafprocedure ook onder juristen steeds meer omstreden topics. Aan het laatstgenoemde euvel poogden sommige staten - met weinig resultaat overigens iets 'te doen' ${ }^{34}$; op het stuk van de beide eerder genoemde gebeurde er helemaal

Het strafproces in de Ommelanden tusschen Eems en Lauwers van 1602 tot 1749 (dissertatie Groningen; Amersfoort, 1920) 401-404.

30. Vergelijk O. Moorman van Kappen, 'Histoire des Tsiganes aux Pays-Bas. L'évolution du statut des 'Pains' ou 'Egyptiens' dans les Pays-Bas du Nord (1420-土1750)', Acta Historiae Neerlandica, III (Leiden, 1968) 160-188.

31. Schorer, Vertoog, 95.

32. $\mathrm{Al}$ in $\mathbf{1 7 0 2}$ verscheen te 's-Gravenhage een Nederlandse vertaling van A. Nicholas' Si la torture... (Amsterdam, 1681) onder de titel Onderzoek uit zeedelessen en regtsgronden of de pijnbank een seker middel is om geheime misdaden waar te maken. De auteur, president van het parlement van Dyon (1622-1695), betoonde zich - lang voor Beccaria en Voltaire - een tegenstander van de pijnbank. Nog oudere bestrijders van de pijnbank waren hier te lande onder meer de bekende Arnhemse geneesheer Johannes Wier (1515-1588), die fel ten strijde trok tegen occultisme, heksengeloof, heksenprocessen en ... de tortuur-vergelijk J. J. Cobben, De opvattingen van Johannes Wier over bezetenheid, hekserij en magie (dissertatie VU; Assen, 1960) en Daniël Jonktijs, De pijnbank wedersproken en bematigt (Rotterdam, 1651).

33. Vergelijk E. Landsberg, Geschichte der Deutschen Rechtswissenschaft (Dritter Abtheilung, Erster Halbband, Text und Noten; München-Leipzig, 1898, ongewijzigde herdruk Aalen, 1957) (416: 'Unter allen solchen kriminalistischen Lieblingsfragen der Aufklärung behauptet seit Beccaria's Anregung unbedingt den Vorrang der Streit um die Todesstrafe).

34. Vergelijk met betrekking tot dergelijke - vruchteloze - strevingen in Holland: J. M. Kemper, Crimineel Wetboek voor het Koningrijk Holland. Met eene inleiding en aanmerkingen, I (niet verder 
niets $^{35}$. Die onvrede van althans een aantal juristen ${ }^{36}$ met het bestaande strafrecht sproot niet alleen voort uit eigen praktijkervaringen, maar werd tevens gevoed door buitenlandse invloeden, waarbij niet alleen te denken valt aan die van de zogenaamde Verlichting in het algemeen, maar ook aan de belangrijke en innoverende ontwikkelingen, die zich elders in Europa in die eeuw manifesteerden.

Over de invloed ook hier te lande van Cesare Beccaria's (1738-1794) Dei delitti e delle pene (1764), waarvan in 1768 te Amsterdam een op de Franse vertaling van Morellet gebaseerde Nederlandse vertaling verscheen ${ }^{37}$, is reeds zoveel geschre$\operatorname{ven}^{38}$, dat niet in nodeloze herhalingen behoeft te worden vervallen. Zijn invloed hier te lande op een niet gering aantal vooruitstrevende intellectuelen - juristen èn niet-juristen -is onmiskenbaar geweest, al veranderde er feitelijk voorshands niets ${ }^{39}$.

DE INVLOED VAN DE VERLICHTING OP STRAFRECHTSWETENSCHAP EN STRAFWETGEVING BUITENSLANDS

Maar Beccaria was bepaald niet de enige Italiaanse 'criminalist' die in die tijd van zich deed spreken, ook al kan in het bijzonder zijn werk niet alleen in Italië, maar elders - vóór alles in Frankrijk, maar eveneens in onder meer Oostenrijk, Duitsland en Engeland - als een tournant de l'histoire in de evolutie van het strafrechtelijke denken beschouwd worden. In de tweede helft van de achttiende eeuw kende Italië een grote opbloei van de strafrechtswetenschap, waarvan de invloed een onmiskenbaar transalpijns karakter aannam ${ }^{40}$.'Penalisten' als Romagnosi,

verschenen, Amsterdam, 1809) 72-80, alsmede de anonieme en titelloze bijdrage in de Algemeene Konst- en Letterbode voor het jaar 1805 (Haarlem, 1805) 202-203. Voorts J. W. Bosch, 'Korte aantekeningen over de uitwendige geschiedenis der Hollandse hervormingsplannen van het strafproces in de XVIIle eeuw', Tijdschrift voor rechtsgeschiedenis, XXI (1953) $59 \mathrm{vlg}$.

35. Vergelijk Cesare Beccaria, Over misdaden en straffen (ingeleid, van aantekeningen voorzien en vertaald door J. M. Michiels; Antwerpen-Zwolle, 1971) 202-205.

36. Naast bestrijders van de pijnbank als Schorer, Amalry en Reinar waren er ook voorstanders (Vitringa, Calkoen, Voorda). Al even verdeeld lagen de meningen over de doodstraf, waarbij opvalt, dat niet alle tegenstanders van de tortuur tevens tegenstanders van de doodstraf waren. Ook een indeling in 'verlichte' vernieuwingsgezinden inzake pijnbank en doodstraf versus 'conservatieve' voorstanders van handhaving dezer instituten blijkt moeilijk te maken. Vergelijk De Monté verLoren, Geschiedenis Strafrechtswetenschap, 119.

37. Verhandeling over de misdaaden en straffen... De anonieme vertaler was wellicht Abraham Perrenot. Vergelijk W. H. Nagel, 'Beccaria en Calkoen', Tijdschrift voor Strafrecht, LXXVII (1968) 73 , nt. 15 .

38. Laatstelijk door Michiels in zijn voortreffelijk gedocumenteerde inleiding bij de nieuwe Nederlandse vertaling van Beccaria's werk, waarnaar bij dezen zij verwezen: Cesare Beccaria, Over misdaden en straffen, 202-216 en 483-483 (bibliografie). Hieraan kan nog worden toegevoegd J. Allersma, 'Beccaria's debuut in Holland', Tijdschrift voor Criminologie, XIX (1977) 208-212.

39. Vergelijk De Monté verLoren, Geschiedenis Strafrechtswetenschap, 75-79.

40. Vergelijk U. Spirito, Storia del diritto penale italiano, da Cesare Beccaria ai giorni nostri (Turijn, 
Pagano, Cremani, De Soria, Renazzi en Filangieri bleven ook ten noorden van de Alpen niet ongelezen. Evenals Beccaria's traktaat vielen ook hun geschriften met name in Frankrijk, in Duitsland en in Oostenrijk in intellectuele kringen in een gunstige voedingsbodem, in Frankrijk 'voorbewerkt' door vooral Montesquieu (1689-1755) en Voltaire (1694-1778), in het Duitstalige gebied door Hugo de Groots in zijn De jure belli ac pacis (1625) verdisconteerde strafrechtstheorie en voorts door verkondigers van rationalistisch-natuurrechtelijke denkbeelden als Samuel von Pufendorf (1632-1694), Christian Thomasius (1655-1728) en de 'school' van Christian Wolff $(1679-1754)^{41}$.

In Frankrijk sympathiseerden vooraanstaande intellectuelen als Morellet, Voltaire, Brissot de Warville, Diderot, Mirabeau, Roederer en Servan hevig met Beccaria's denkbeelden en volgens Mazzacane ontstond zelfs 'toute une école nouvelle de criminalistes ${ }^{\mathbf{4 2}}$. Naarmate het revolutiejaar naderde kregen zij meer en meer de wind in de zeilen.

In Oostenrijk trad vooral Joseph von Sonnenfels (1733-1817), sinds 1763 hoogleraar in de Polizei- und Kameralwissenschaft aan de universiteit van Wenen, als voorvechter van strafrechtshervorming, als bestrijder ook van de tortuur en de doodstraf naar voren. In Duitsland was Karl Ferdinand Hommel (1722-1781), hoogleraar te Leipzig, zijn evenknie. Hij deed onder meer een becommentarieerde Duitse vertaling van Beccaria's 'unsterbliches Werk' het licht zien ${ }^{43}$. En in hun kielzog volgden vele epigonen van secundaire garnituur zoals Justus Claproth, Johann Christian Ernst von Quistorp, Johann David Michaelis, Globig en Huster. In Frankrijk resulteerden de nieuwe verlichte denkbeelden op strafrechtelijk ge-

1932); E. Pessina, 'Il diritto penale in Italia da Cesare Beccaria fino alla promulgazione del codice penale vigente (1764-1890)', in: Enciclopedia del diritto penale italiano, II (Milaan, 1906) 539-768; A. Mazzacane, 'La diffusion de la doctrine des pénalistes italiens depuis le 18ième siècle', Bulletin d'information de l'Association Internationale d'Histoire du Droit et des Institutions, $\mathrm{X}$ (januari 1975) 28-30.

41. Vergelijk Conrad, Deutsche Rechtsgeschichte, II, 436-438; uitvoeriger: O. Fischl, Der Einflusz der Aufklärungsphilosophie auf die Entwicklung des Strafrechts... (1913; ongewijzigde herdruk Aalen, 1973); Van Hamel, Strafrecht, 67-69, volgens wie 'juist in dezen tijd wegens deze belangstelling der wijsbegeerte de groote, tot heden voortgezette strijd der strafrechtstheorieën ontbrandde'. In Frankrijk was het vooral de door Voltaire gevoerde 'publiciteitscampagne' tegen het proces-Jean Calas (1671-'72) en eenige andere zogenaamde 'gerechtelijke dwalingen' in strafzaken, die de stoot gaven tot een kritische bezinning op de vigerende strafrechtspraktijk. Vergelijk Beccaria, Over misdaden, 253-255.

42. Ibidem, 227-233; Mazzacane, 'Pénalistes Italiens', 29. Vergelijk ook Jacques Godechot, Les institutions de la France sous la révolution et l'empire (2e dr.; Parijs, 1968) 140-141; J. van Kan, 'De verwachting des volks in 1789 ten aanzien van de codificatie', Tijdschrift voor rechtsgeschiedenis, I (1918-1919) 359-389 (in het bijzonder 383-385); idem, 'De rechtsgedachte der codificatie-beweging in Frankrijk voor de Revolutie', ibidem, 191-229.

43. Conrad, Deutsche Rechtsgeschichte, II, 438-440. Vergelijk uitvoeriger over Von Sonnenfels: Landsberg, Geschichte Rechtswissenschaft, Text, 401-404, Noten 263-264. Over Hommel ibidem, Text, 386-400, Noten, 253-261. 
bied eerst na de revolutie in daadwerkelijke veranderingen in de wetgeving. $\mathrm{Na}$ de afschaffing van de pijnbank in oktober $1798^{44}$, na de opneming van het beginsel 'geen straf zonder voorafgegane wettelijke strafbepaling' in artikel 8 van de $D e ́-$ claration des droits de l'homme et du citoyen ${ }^{45}$ en na een voorlopige zuivering van de strafprocedure, geregeld door de Ordonnance criminelle van 1670, van de ernstigste uitwassen, kwam het in de tweede helft van 1791 tot een ingrijpender herziening van het materiële en formele strafrecht. De 'eerste' Code pénal van 1791 droeg duidelijk een Beccariaans geïnspireerd karakter. De doodstraf bleef na heftige debatten in de Assemblée Nationale behouden, zij het dat men de executie ervan bij besluit van 20 maart 1792 'moderniseerde' en 'humaniseerde' door middel van een apparaat, door dr. Louis uitgevonden, maar abusievelijk naar dr. Guillotin genaamd $^{46}$. De toenemende criminaliteit leidde tot een verscherping van de op te leggen straffen bij de wet van 25 oktober 1795, de Code des délits et des peines (zogenaamde Code Merlin). In april 1801 werd een commissie tot het ontwerpen van een meer definitieve strafwetgeving ingesteld, welker arbeid uiteindelijk resulteerde in de Code d'instruction criminelle van 1808 en de Code pénal van 1810, beide op 1 januari 1811 in werking getreden. Vooral de Code pénal, waarin de gedachte van de zogenaamde generale preventie het Leitmotiv vormt en waarop Jeremy Benthams utilisme van invloed is geweest, betekende een stap terug, onder meer op het stuk van het straffenstelsel en de rigide straftoemetingsregels ${ }^{47}$.

In de Duitstalige gebieden daarentegen vonden de nieuwe denkbeelden eerder gehoor, ook bij 'verlicht' absolutistische vorsten als Jozef II en Frederik de Grote, en

44. Godechot, Institutions, 144 (10 okt. 1798).

45. Art. 8: La loi ne doit établir que des peines strictement et évidemment nécessaires, et nul ne peut être puni qu'en vertu d'une loi établie et promulguée antérieurement au délit, et légalement appliquée (curs. v. d. schr.). Dit later door Johann Paul Anselm von Feuerbach (1775-1833) als 'rechtsstatelijk' principe zo scherp geformuleerde legaliteitsbeginsel 'Nullum crimen, nulla poena sine [praevia] lege [poenali]', geheel en al passend in diens generaal-preventieve leer van de zogenaamde psychologische dwang, kwam ook al voor in Beccaria's tractaat (hfdst. 3) en was in de loop van de achttiende eeuw in vooral de Duitse 'verlichte' strafrechtelijke literatuur reeds gemeengoed geworden; vergelijk G. E. Mulder, 'P. J. A. Feuerbach en het Crimineel Wetboek voor het koningrijk Holland', Uit het recht. Rechtsgeleerde opstellen aangeboden aan mr. P. J. Verdam (Deventer, 1971) 176. Zo betoogde onder meer J. Chr. E. von Quistorp (1737-1795) in diens Grundsätze des deutschen peinlichen Rechts (Rostock, 1770) I $\$ 29$ in fine en $\S 32$, dat het begrip misdaad vooronderstelt 'dasz ein Gesetz im Staate vorhanden sey, welches auf dasselbe eine Strafe setzet'. Zelfs kwam in verscheidene achttiende-eeuwse Duitse en Oostenrijkse strafwetgevingen het legaliteitsbeginsel met zoveel woorden voor, zoals in Jozef II's Allgemeines Gesetzbuch über Verbrechen und derselben Bestrafung (13 jan. 1787) (I $\$ \$ 1,12 / 13,19$; II $\$ \$ 1 \mathrm{en} 8)$, zij het meer als een norm voor de rechter dan voor de justitiabelen. Vergelijk Allgemeines Landrecht für die Preuszischen Staaten (1794) II. 20.9: 'Handlungen und Unterlassungen, welche nicht in den Gesetzen verboten sind, können als eigentliche Verbrechen nicht angesehen werden ....

46. Godechot, Institutions, 152; A. J. M. Kunst, Historische ontwikkeling van het recht, I (2e dr.; Zwolle, 1969) 146, nt. 2.

47. Ibidem, 155. 
daar kwam het sinds het midden van de achttiende eeuw tot wettelijke hervormingen, zij het dat die qua inhoud nogal eens 'achterliepen' op de ideologie. Was de in Oostenrijk in 1768 als algemeen strafwetboek ingevoerde Constitutio criminalis Theresiana nog van een sterk traditioneel en conserverend karakter, de tortuur en de doodstraf werden nadien in fasen afgeschaft; het voornaamste bezwaar tegen afschaffing van de doodstraf waren de kosten van de vervangende strafinrichtingen. De Theresiana werd in 1787 door een nieuw strafwetboek vervangen, waarin Jozef II zelf de hand had gehad ${ }^{48}$. In de Oostenrijkse Nederlanden strandden de Jozefinistische hervormingsstrevingen, op strafrechtelijk gebied primair gericht op afschaffing van de tortuur en de doodstraf, in 1787 op de Brabantse opstand. Deze te progressief blijkende vernieuwingen waren krachtig ondersteund en ten dele ook voorbereid door een zeer vooruitstrevend jurist, Goswin de Fierlant (1736-1804), raadsheer in en later president van de Grote Raad van Mechelen ${ }^{49}$.

In Pruisen ten slotte kwam het onder Frederik de Grote slechts tot partiële, maar bepaald niet onbelangrijke hervormingen van het strafrecht, die later werden verwerkt in het in 1794 ingevoerde Allgemeines Landrecht für die Preuszischen Staaten, welke codificatie als één van Frederik de Grote's geestelijke erfenissen beschouwd kan worden ${ }^{50}$. Curiositeitshalve zij nog gewezen op de befaamde Nakaz van tsarina Catharina II, een uitvoerige, uit 1767 daterende instructie voor een Russische codificatiecommissie, die als het ware bol stond van verlichte denkbeelden, waaronder die van Beccaria en Von Sonnenfels. Deze instructie - een soort programma voor hervorming van de wetgeving - trok alom in West-Europa sterk de aandacht en werd in vele talen vertaald, onder meer in het Nederlands ${ }^{51}$.

Het feit, dat er vooral in de Duitstalige gebieden in de tweede helft van de achttiende eeuw 'beweging' kwam in de voordien traditionalistische strafwetgeving, betekende op zijn beurt weer een stimulans voor de dientengevolge opbloeiende strafrechtswetenschap aldaar. En dat proces had weer ten gevolge, dat, vooral na het midden van de achttiende eeuw, naast Beccaria's traktaat de Duitse strafrechtelijke

48. Conrad, Deutsche Rechtsgeschichte, II, 426-428, 441, 443.

49. Beccaria, Over misdaden, 216-226, alwaar nadere literatuurverwijzingen.

50. Conrad, Deutsche Rechtsgeschichte, II, 444-447. De 20ste titel van het tweede deel van het Allgemeines Landrecht behelst echter alleen een wettelijke- regeling van het materiële strafrecht voor zover op Verbrechen betrekking hebbend. Vergehen (overtredingen) bleven er buiten. Het formele strafrecht werd eerst in 1805 in de Kriminalordnung für die Preuszischen Staaten gecodificeerd. Enkele voorbeelden van 'verlichte' maatregelen van Frederik de Grote: in 1749 beval hij tot radbraking of verbranding veroordeelden vóbr de executie van deze straffen op een voor het toeschouwende publiek niet merkbare wijze te smoren. Voorts schafte hij de zogenaamde hoerenstraffen voor ongehuwde moeders af 'damit die in Unehren schwanger gewordenen Weibsleute um so weniger Bedenken finden mögen, ibre Schwangerschaft bekannt werden zu lassen'. Ook gelastte hij een inperking van de toepassing van de bijkomende straf van eerloosverklaring (infamie) met de motivering, dat een ex-gedetineerde het toch al moeilijk genoeg had 'fernerhin sein Brot auf ehrliche Art zu verdienen'.

51. Beccaria, Over misdaden, 68 en uitvoeriger Kemper, Crimineel Wetboek, 13-18. 
literatuur onder bij de strafrechtspleging betrokken juristen hier te lande aan invloed begon te winnen. In die belangstelling voor wat in de Duitse staten en in Oostenrijk op strafrechtelijk gebied gaande was deelden - quod notandum est - ook die Duitstalige auteurs, die nu niet bepaald van een uitgesproken 'progressieve' signatuur waren en zelfs de zeventiende-eeuwer Benedictus Carpzovius (1595-1666) met zijn sterk tegen de zestiende-eeuwse Caroline-ordonnantie aanleunende Practica ... rerum criminalium, zij het dan in de achttiende-eeuwse becommentarieerde ver$\operatorname{sies}^{52}$.

Dusdoende is het verklaarbaar dat het inleidende lijstje van strafrechtelijke literatuur, dat Johannes van der Linden (1756-1835), één van de hekkesluiters van onze oud-vaderlandse juristen, in zijn Regtsgeleerd, Practicaal en Koopmans Handboek anno 1806 aan zijn lezers presenteert, grotendeels uit Duitse strafrechtelijke literatuur van na 1750 bestaat $\left(B o ̈ h m e r^{53}\right.$, Meister ${ }^{54}$, Püttmann $^{55}$, Wieland ${ }^{56}$, Von Quistorp ${ }^{57}$, Kleinschrod ${ }^{58}$ en Grolman ${ }^{59}$ ). Beccaria komt er natuurlijk ook op

52. Bij voorbeeld $B$. Carpzovii Practica nova imperialis Saxonica rerum criminalium cum observationibus J. S. F. Böhmeri (3 dln.; Frankfort, 1758;1e dr. 1635). Carpzov [ius] maakte onderscheid tussen crimina levia, atrocia en atrocissima, welke driedeling van strafbare feiten in de latere Code pénal is weer te vinden (contraventions, délits en crimes).

53. Johann Samuel Friedrich von Böhmer (1704-1772), die onder meer als eerste een systematisch wetenschappelijk overzicht van het materiële en formele strafrecht schreef: Elementa jurisprudentiae criminalis (Halle, 1774; 1e dr. 1732). Vergelijk over deze: G. Boldt, Johann Samuel Friedrich von Böhmer und die gemeinrechtliche Strafrechtswissenschaft (Berlijn-Leipzig, 1936).

54. Christian Friedrich Georg Meister ('den Alten', 1718-1782) schreef onder meer Principia juris criminalis Germaniae communis (Leipzig, 1781; 1e dr. Göttingen, 1755). Diens zoon Georg Jakob Friedrich Meister (1755-1832) publiceerde in 1789 te Göttingen een gelijknamig werk. Vergelijk over de beide Meisters: Landsberg, Geschichte Rechtswissenschaft, Text, 304-307, 422-423, Noten, 204-205, 273.

55. Josias Ludwig Ernst Püttmann (1730-1796) publiceerde onder meer Elementa Juris Criminalis (1e dr.; Leipzig, 1779) (Landsberg, Geschichte Rechtswissenschaft, Text, 477-479, Noten, 303-304).

56. Ernst Karl Wieland, hoogleraar in de filosofie te Leipzig, schreef onder meer Geist der peinlichen Gesetze (3 dln.; Leipzig, 1783) (Landsberg, Geschichte Rechtswissenschaft, Text, 412).

57. Johann Christian Ernst von Quistorp (1737-1795), Grundsätze des Deutschen Peinlichen Rechts (2 dln.; Rostock, 1792, le dr. Rostock-Leipzig, 1770) (Landsberg, Geschichte Rechtswissenschaft, Text, 408-411, Noten, 266-267).

58. Gallus Aloys Caspar Kleinschrod (1762-1824) publiceerde onder meer een Entwurf eines peinlichen Gesetzbuches für die Kurpfalzbaierischen Staaten (München, 1802) - waartegen P. J. A. Feuerbach zich richtte in zijn Kritik des Kleinschrodischen Entwurfes zu einem peinlichen Gesetzbuche für die Kurpfalzbaierischen Staaten (München, 1804 ) - en voordien zijn Systematische Entwicklung der Grundbegriffe und Grundwahrheiten des peinlichen Rechts nach der Natur der Sache und der positiven Gesetzgebung ( 3 dln.; Erlangen, 1794-1796). Vergelijk over deze Würzburger hoogleraar: Landsberg, Geschichte Rechtswissenschaft, Text, 461-465, Noten, 296-297.

59. Karl Ludwig Wilhelm Grolman (1775-1829), Grundsätze der Kriminalrechtswissenschaft (Gieszen, 1798). Met L. H. von Almendingen en J. P. A. Feuerbach gaf hij de Bibliothek für die peinliche Rechtswissenschaft und Gesetzeskunde uit (1797-1804, 3 dln.).

Vergelijk uitvoeriger over de Duitse strafrechtsliteratuur uit het verlichtingstijdperk: Conrad, Deutsche Rechtsgeschichte, II, 454-455 s.v. 'Schrifttum'; R. von Hippel, Deutsches Strafrecht, I, 
voor, maar van de oud-vaderlandse auteurs alleen nog Antonius Matthaeus (II). De overige raadt hij zijn lezers af:

$\mathrm{Zij}$ bevatten meestal eene opeenstapeling van aanmerkingen, die meer verwarren dan ophelderen en bijna allen dragen de blijken van de mindere beschaafdheid van den tijd, waarin zij schreven. Zedert men het stuk van het straffen der misdaaden meer wijsgeerig en menschkundig heeft beginnen te behandelen, heeft hetzelve eene geheel andere gedaante aangenomen... ${ }^{60}$.

Het was aan de 'criminalisten' in de codificatiecommissie - 1798 om die 'andere gedaante' een wettelijke vorm te geven ...

BEKNOPT OVERZICHT VAN DE WORDINGSGESCHIEDENIS VAN HET ONTWERP-LIJFSTRAFFELIJK WETBOEK 1804

Over de geschiedenis van de codificatiegedachte in de eerste jaren van de Bataafse Republiek, over die van de in 1798 ingestelde codificatiecommissie en over de geschiedenis van de totstandkoming van het ontwerp-Lijfstraffelijk Wetboek 1804 zal ik zeer kort zijn. Over de beide eerstgenoemde onderwerpen is in de laatste vijftien jaren het een en ander gepubliceerd ${ }^{61}$, terwijl zeer kort geleden mijn 'Uitwendige schets der wordingsgeschiedenis van het ontwerp-Lijfstraffelijk Wetboek$1804^{\prime}$ in druk verscheen, waarnaar bij deze zij verwezen ${ }^{62}$.

Volstaan zij daarom met het strikt noodzakelijke ${ }^{63}$. Volgens artikel 28 van de 'Burgerlijke en Staatkundige Grondregels', voorafgaande aan de staatsregeling1798, moest er binnen twee jaren een algemeen wetboek van burgerlijk-, straf- en procesrecht voor de Bataafse Republiek worden ontworpen en ingevoerd. Aan de

Allgemeine Grundlagen (Berlijn, 1925); J. A.'van Hamel, 'Strafrechtspolitiek van voor honderd jaar', De Gids, II (1909) 11 vlg. Uitvoeriger (incl. bio- en bibliografische gegevens): Landsberg, Geschichte Rechtswissenschaft, passim, alsmede noot 41.

60. Van der Linden, Regtsgeleerd Handboek, Ixiii-lxiv.

61. Vergelijk onder meer: J. Th. de Smidt, Codificatie-perikelen (inaugurele rede Leiden, 1966); J. Th. de Smidt en A. H. Huussen jr., ed., Bronnen van de Nederlandse codificatie sinds 1798, I, Stukken van algemene aard. De gedrukte ontwerpen van 1804 en hun voorgeschiedenis, verz. door $m r . H . A a(\dagger)$ (Werken van de Ver. t. uitg. d. Bronnen v. h. Oud-Vad. Recht. 3e reeks XXII; Utrecht, 1968). Vergelijk voorts de literatuur vermeld in Moorman van Kappen, 'Uitwendige Schets', 113, nt 1 en 114, nt 7-9. Voor de oudere literatuur vergelijk N. K. F. Land, Inleiding tot de verklaring van het Burgerlijk Wetboek (Haarlem, 1899) 93-112; Briefwisseling van eenige regtsgeleerden over de aanstaande Nederlandsche wetgeving (Leiden, 1819) passim; S. J. Hingst, 'Geschiedenis der codificatie', Rechtsgeleerde Bijdragen en Bijblad, II (1886-1887) 1-132.

62. Hierin zijn tevens verwerkt de voornaamste gegevens bij Kemper, Crimineel Wetboek, 81-113. 63. Voor nadere bijzonderheden betreffende het navolgende (biografische gegevens betreffende de daarin genoemde juristen daaronder begrepen) vergelijk Moorman van Kappen, 'Uitwendige Schets', passim, aangehaald in noot 8 . 
totstandkoming van dit voorschrift was heel wat geharrewar tussen enerzijds unitaristen, voor wie het beginsel 'één staat één recht' vanzelfsprekend was, en anderzijds taai en taktisch verzet biedende federalisten voorafgegaan, alsook de instelling - in oktober 1796 - van een civiele en een strafrechtelijke codificatiecommissie. Aangezien vrijwel alle daarin benoemden voor de eer bedankten liep dit laatste op een eclatant echec uit.

Ter uitvoering van het zoëven genoemde codificatievoorschrift ging het uitvoerend bewind eind september 1798 over tot de instelling van een - eigenlijk tweede codificatiecommissie, die van 1798 , bestaande uit twaalf juristen, onder wie zes Hollanders. Deze verdeelde zich intern in een 'civiele' subcommissie van zeven en een 'criminele' subcommissie van vijf leden. $\mathrm{Na}$ enige personele wisselingen bestond de criminele subcommissie sinds mei 1799 uit de mrs. J. in de Betouw, W. A. de Beveren, B. Donker Curtius, C. T. Elout en H. A. Kreet. Door allerlei omstandigheden werd het eind 1799 eer deze commissie met haar werkzaamheden goed en wel van start ging. De taken werden intern verdeeld, de leden makkten hun 'huiswerk' hoofdzakelijk thuis en communiceerden onderling schriftelijk alsook op periodiek gehouden meerdaagse bijeenkomsten. Als primus in dit nijver werkende gezelschap ontpopte zich weldra Elout.

Er werd inderdaad hard gewerkt, want op een op 24 april 1801 gehouden bijeenkomst van de codificatiecommissie in pleno legde de criminele subcommissie een vier boeken en 952 artikelen tellend ontwerp van 'criminele wetten', een ontwerpcodificatie van het materiële strafrecht derhalve, aan de vergadering voor. Daarop volgde de grote domper, want aangezien de 'civilisten' met hun taak nog verre van gereed waren, besloot de plenaire commissie het ingeleverde ontwerp voorlopig te laten rusten. Pas in april 1803 - het enthousiasme voor een nationale codificatie was intussen, voor zover het er was geweest, aardig weggeëbd - bracht het staatsbewind verandering in deze stationaire toestand, gelastend dat de codificatiecommissie zo spoedig mogelijk het Ontwerp-Lijfstraffelijk Wetboek met enige annexe te codificeren materies moest inleveren met 'postpositie' van alle andere werkzaamheden. Toch duurde het nog tot eind maart 1804 eer de 'civilisten' het ontwerp van commentaar hadden voorzien en de plenaire commissie haar beraadslagingen over het ontwerp begon. Deze beraadslagingen resulteerden in een tamelijk ingrijpende omwerking van het ontwerp-1801, waarmee de heren Elout en Farjon werden belast. In september 1804 legden zij een omgewerkt ontwerp aan de commissie over, die dit na een laatste finale 'resumtie' op 3 oktober 1804 inleverde bij het staatsbewind. Dit college liet het Ontwerp-Lijfstraffelijk Wetboek-1804 eind van dat jaar in gedrukte vorm verschijnen ${ }^{64}$ en zond het tevens ter fine van advies toe aan het na-

64. Stukken door de commissie tot het ontwerpen van een Algemeen Burgerlyk en Lyfstraffelyk Wetboek, overgegeven aan het Staatsbewind der Bataafsche Republiek; bevattende de ontwerpen van eene Inleiding van het recht in het algemeen, het Lyfstraffelyk Wetboek en van Wetten omtrent 
tionaal gerechtshof ${ }^{65}$, zulks conform de door de staatsregeling-1801 (art. 84) voorgeschreven procedure.

INHOUDSOVERZICHT EN KARAKTERISTIEK VAN HET ONTWERP-LIJFSTRAFFELIJK WETBOEK 1804

Het Ontwerp-Lijfstraffelijk Wetboek-1804, dat 968 artikelen telt, is ingedeeld in vier boeken, respectievelijk handelend 'Van misdaden en straffen in het algemeen' (boek I), 'Van misdaden tegen den staat en deszelfs leden in het algemeen' (boek II), 'Van misdaden tegen byzondere persoonen' (boek III) en 'Van misdaden van gemengden aart' (boek IV). Elk boek is ingedeeld in een aantal hoofdstukken, enkele daarvan nog weer in afdelingen. De artikelen zijn per hoofdstuk genummerd.

In het eerste boek - wat men tegenwoordig zou noemen het 'algemeen deel' van het strafwetboek - wordt een aantal strafrechtelijke voorschriften van algemene aard gegeven. Met name worden daarin een aantal algemene begrippen en beginselen gedefinieerd en geregeld, die van belang zijn voor de berechting van de in de drie volgende boeken behandelde onderscheidene misdaden en die tezamen het wat men thans zou noemen - 'bijzonder deel' vormen. Het onderscheid tussen de in boek II en boek III geregelde 'misdaden' berust op (een bepaalde visie op) een verschil qua aard en belang van het door een gepleegde misdaad primair aangetaste rechtsgoed. Hoewel het Ontwerp-Lijfstraffelijk Wetboek erkent, dat 'alle misdaden het geluk van den burgerstaat stooren' (boek II, hfdst. i, art. 1), benadelen sommige misdaden de staat 'onmiddelyk', andere slechts 'middelijk'. Onmiddellijk thegen de staat gerichte misdrijven 'zijn dezulken, welke tegen den burgerstaat in het" algemeen regelrecht zijn ingericht en worden dierhalven eigenlijke staatsmisdaden genoemd' (ibidem, art. 2). Deze zijn in boek II geregeld. Middellijk tegen de staat gerichte misdrijven zijn die,

'welke regelrecht tegen bijzondere persoonen zijn ingericht en den staat alleenlijk in de gevolgen benadeelen, alzoo de zekerheid en veiligheid van den staat zelv' afhangt van de zekerheid en veiligheid van deszelfs leden' (ibidem, art. 3).

Deze zijn geregeld in boek III. Het belang van de onmiddellijk en de middellijk tegen de staat gerichte misdaden wordt verschillend gewaardeerd, want de onmid-

het bewys (Den Haag, 1804). De genoemde inleiding en de wetten omtrent het bewijs verschenen met hun wordingsgeschiedenis en annotaties in de in noot 61 genoemde bronneneditie van $\mathrm{Aa}$, De Smidt en Huussen.

65. De staatsregelingen van 1801 en 1805 maken gewag van 'Nationaal Geregtshof', de 'Constitutionele Wetten' van 1806 afwisselend van 'Hoog Nationaal Geregtshof' (artt. 71 en 73) en van 'Nationaal Geregtshof' (artt. 74-78). In de praktijk noemde dit rechterlijke college zich 'Hoog Nationaal Geregtshof'. 
dellijk tegen de staat gerichte misdaden worden strafwaardiger geacht (boek I, hfdst. ii, art. 13). Het ontwerp kent overigens nog een tussenvorm tussen beide genoemde categorieën misdaden (boek IV).

Het Ontwerp-Lijfstraffelijk Wetboek-1804 bevat overigens geenszins een ontwerpcodificatie van het gehele 'burgerlijke' 66 materiële strafrecht, want zogenaamde overtredingen zijn er niet in en onder begrepen ${ }^{67}$.

In boek I worden achtereenvolgens aan de orde gesteld de misdaad in het algemeen (hfdst. i) ${ }^{68}$, het onderscheid en de waardering der misdaden (hfdst. ii), de straffen in het algemeen (hfdst. iii) ${ }^{69}$, de waardering en toepassing der straffen benevens derzelver evenredigheid met de misdaden (hfdst. iv), de beschuldiging en derzelver gevolgen (hfdst. v) en het ophouden en vernietigen der beschuldigingen en straffen (hfdst. vi). De beide laatstgenoemde onderwerpen behoren naar de tegenwoordige opvatting veeleer tot het strafprocesrecht, het executierecht daaronder begrepen $^{70}$.

De 'eigenlijke staatsmisdaden' zijn in het tweede boek geregeld. Onderscheiden worden enerzijds misdaden tegen 'de uitwendige veiligheid van de staat' (hfdst. ii), anderzijds" die tegen 'de inwendige veiligheid, rust en orde van den staat' (hfdst.

66. In de zin van niet-militair strafrecht.

67. Vergelijk art. 6 van de wet tot arrestatie van het Crimineel Wetboek van 1809, d.d. 31 december 1808: 'Het Crimineel Wetboek strekt zich geenszins uit tot zoodanige kleine overtredingen, de dagelijksche policie of plaatselijke administratie betreffende, waarvan de gestelde straf eene boete van vijftig guldens of eene driedaagsche gevangenis niet te boven gaat'. J. van de Poll, Verzameling van vaderlandsche wetten en besluiten... (Amsterdam, 1840) 427.

68. Misdaad wordt omschreven als een 'overtreeding eener wet, welke het doen of laten van eenige daad, onder bedreiging van straf, gebiedt of verbiedt' (art. 1). Voorts komen onder meer aan de orde het verschil tussen 'boos' opzet en schuld ('schuldig pligtsverzuim') en allerlei vormen van medeplegen van een misdaad. Ook de nulla poena-regel wordt verwoord: 'Er bestaat geene misdaad zonder voorafgegane wet' (art. 7).

69. Straf wordt gedefinieerd als 'dat nadeel, ' $t$ welk de wet aan het bedryven van misdaden verknogt heeft, tot beveiliging van den burgerstaat' (art. 1). Alle nevenoogmerken van de straffen moeten daaraan ondergeschikt blijven (art. 2). Deze en andere het generaal-preventieve karakter van de straf op de voorgrond stellende bepalingen zouden een beïnvloeding in dezen door Feuerbachs leer kunnen doen veronderstellen. Terecht heeft Mulder ('Feuerbach', 177-178) van twijfel te dezen blijk gegeven en de veronderstelling geuit, dat veeleer zowel Feuerbach als de 'makers van het ontwerp-1804 uit dezelfde bron hebben geput'. Inderdaad is naar ons voorlopig oordeel de invloed van Feuerbach op het Ontwerp-Lijfstraffelijk Wetboek-1804 zeer gering geweest, zulks alleen al om redenen van chronologische aard: vór 1804 was zijn invloed hier te lande nog nauwelijks te bespeuren. Wat de straffen betreft: het Ontwerp-Lijfstraffelijk Wetboek kent straffen tegen het leven, het lichaam (lijfstraffen), tegen de vrijheid (voornamelijk gevangenis- en verbanningsstraf), tegen de eer en tegen het vermogen (waaronder echter niet de geldboete) alsmede 'tuchtigingsstraffen' (opsluiting op water en brood en kastijding) voor 'jonge boosdoeners' (artt. 30-31). Daarnaast kent het ontwerp 'gepaste middelen van voorziening' - een soort maatregelen dus - tegen 'kwaadwilligen' en 'onzinnigen'.

70. Men bedenke evenwel, dat er anno 1804 in de Bataafse Republiek nog steeds geen uniform procesrecht gold. Vergelijk Moorman van Kappen, 'Een ongeschreven hoofdstuk', passim. 
iii). Tot de eerste categorie behoren 'staatsverraad' (aan vreemde mogendheden) ${ }^{71}$ en 'staatsschennis' ${ }^{72}$. De eerstbedoelde subcategorie wordt met een 'vijandig oogmerk' tegen de staat gepleegd, bij de tweede ontbreekt dit vijandig oogmerk en bestaat dit in eigenbelang, wraakzucht, lafhartigheid, vrees of zelfs 'het vermeend belang van den staat' (hfdst. ii, art. 37). Onder de tweede (hoofd)categorie (hfdst. iii) vallen 'schending der regeeringsform' (hfdst. iii, afd. i), 'openlijk geweld' (hfdst. iii, afd. ii), godloochening en godslastering (hfdst. iii, afd. iii) ${ }^{73}$. Als eigenlijke staatsmisdrijven van geheel eigen aard worden ten slotte nog beschouwd misdaden betreffende de geldmunten van de staat (hfdst. iv) en die betreffende staatspapieren, geldswaarde hebbende (hfdst. v).

In het derde boek treft men de misdaden 'tegen bijzondere persoonen' aan, zoals die tegen het leven (hfdst. i) - onderscheiden in moord ${ }^{74}$, doodslag, manslag en tweegevecht, terwijl de vijfde afdeling handelt over 'onstrafbare doodslag', gedefinieerd als 'ontoerekenbare berooving van een anders leven'75 - , die tegen het lichaam (hfdst. ii), zoals mishandeling, die tegen de kuisheid (hfdst. iii) ${ }^{76}$, die tegen de vrijheid (hfdst. iv), die tegen de eer (hfdst. v), samengevat onder het begrip 'hoon" ${ }^{77}$, en ten slotte die tegen de bezittingen (hfdst. vi) ${ }^{78}$.

Het vierde boek handelt over 'misdaden van gemengden aart', die beschouwd wor-

71. Gedefinieerd als 'die misdaad, door welke het bestaan en de onafhanglykheid van den staat, ten aanzien van andere volken met een vyandig oogmerk wordt benadeeld of in gevaar gebragt' (hfdst. ii, art. 2).

72. Omschreven als 'het bedryven van zoodanige daden, door welken de uitwendige veiligheid van den staat onmiddelyk, doch zonder vijandig oogmerk geschonden of in gevaar gebragt wordt' (ibidem, art. 35).

73. Ook in het Pruissische Allgemeines Landrecht van 1794 worden Religionsverbrechen tot de Staatsverbrechen gerekend (II, $20 . \$ 214 \mathrm{vlg}$ ). Hetzelfde beginsel werd trouwens ook in het Oostenrijkse strafwetboek van 1787 gevolgd.

74. Met als bijzondere species kindermoord en vruchtafdrijving.

75. Bk III, hfdst. i, art. 103. Het betreft hier voornamelijk gevallen van doodslag, uit noodweer begaan, welke strafuitsluitingsgrond, zonder beperking tot doodslag, in moderne strafwetboeken in het algemeen deel geregeld pleegt te worden. Als bijzonder geval van onstrafbare doodslag kent het Ontwerp-Lijfstraffelijk Wetboek-1804 de 'man, die eenen anderen in vleeschelyke gemeenschap met zyne vrouw en alzoo in overspel aantreft, en den overspeeler doodt' (art. 127). Zelfs is zo'n doodslag 'onstrafbaar', indien deze plaatsvindt in geval van 'naaste poging' tot overspel, vooropgesteld dat zodanige omstandigheden aanwezig zijn, dat die zo'n naaste poging 'ontwyffelbaar aanduiden' (art. 128). Doodslag 'by louter toeval' is echter 'onstrafbaar' (art. 132).

76. Onderscheiden in overspel, dubbel huwelijk, bloedschande, samenwoning in onecht (concubinaat), vrouwenroof en schaking, verkrachting, ontering en 'onnatuurlijke ontucht', 'welker voornaamste graad onder den naam van sodomie bekend is'.

77. Aan welk delict drukkers en boekverkopers mede schuldig geacht worden, als zij 'eenige hoonende geschriften, prenten of teekeningen drukken, verkoopen en alzoo verspreiden' (art. 15). Art. 14 bepaalt, dat iemand, die een ander een misdaad ten laste legt, 'wier bestaan hy bewyst', straffeloos is, 'mits hy daarvan aan den bevoegden openbaren aanklager kennis geve'.

78. Onderscheiden in brandstichting, inbraak, roof, diefstal, beschadiging van waterkeringen, verduistering van (binnenlandse) grensscheidingen en het bederven en beschadigen van goederen. 
den als een soort tussenvorm van onmiddellijk en middellijk tegen de staat gerichte misdaden, zoals misdaden van ambtenaren (hfdst. i), dat wil zeggen door ambtenaren qua talis gepleegd, meineed (hfdst. ii), valsheid en bedrog (hfdst. iii) ${ }^{79}$ en misdadige bankbreuk (hfdst. iv).

Het Ontwerp-Lijfstraffelijk Wetboek-1804 wordt niet alleen gekenmerkt door een bijzondere uitvoerigheid, maar ook door zijn - zoals latere critici het hebben genoemd - 'leerstelligheid'. Zowel de algemene voorschriften als die betreffende de afzonderlijke 'misdaden' zijn niet alleen uitermate gedetailleerd, maar ook uiterst genuanceerd door een voortdurend streven alle mogelijke schakeringen, verbijzonderingen en uitzonderingen tot hun recht te laten komen, zodat aanzienlijke gedeelten van het ontwerp het karakter van een sterk deductief getint dogmatischrechtswetenschappelijk betoog aannemen ${ }^{80}$, dat zich primair richt tot de rechter, die de strafwet heeft toe te passen. Vele artikelen ervan zijn met andere woorden meer een soort instructienormen voor de rechter dan ge- en verbodsbepalingen voor de justitiabelen ${ }^{81}$.

De reden hiervan wordt duidelijk als men poogt na te gaan uit welke bronnen de samenstellers van het Ontwerp-Lijfstraffelijk Wetboek-1804 hebben geput. Dit zijn namelijk niet primair bestaande binnen- of buitenlandse strafwetten en strafwetboeken geweest, maar wel allerlei achttiende-eeuwse geschriften van 'verlichte' auteurs op het gebied van het strafrecht met een sterk natuurrechtelijke inslag. Het zijn hun deductief-redenerende vertogen, die als het ware 'doorstralen' in het ont-

79. Valsheid wordt omschreven als 'alle zodanige daden, door welken, willens en wetens, het waare wordt verduisterd en verborgen, of ook het onwaare in de plaats van het waare gesteld en opgegeven, tot benadeeling van eens anders recht' (art. 1). Bedrog als 'het grovelyk misleiden en benadeelen van anderen, door bedriegelyke voorgevens' (art. 19).

80. Zulke typisch 'leerstellige' bepalingen zijn bijvoorbeeld Bk I, hfdst. ii, art. 1: 'Niet alle misdaden zyn voor de maatschappije even nadeelig en gevaarlyk; dezelver waardeering dierhalven is onderscheiden'. Art. 2: 'Deze onderscheiding wordt in het algemeen geregeld: I Naar den aart van de misdaad en hare uitwendige voorwerpen; II. Naar den persoon en de omstandigheden van den misdadigen'. In de artt. 3 en 4 worden de misdaden, sub I en II in art. 2 onderscheiden, dan elk weer op drie, respectievelijk vier verschillende wijzen onderverdeeld, aan elk van welke onderverdelingen dan weer een aantal artikelen gewijd worden.

81. Dat deze opvatting omtrent de inhoud van het Ontwerp-Lijfstraffelijk Wetboek-1804 c.a. niet alleen die van het geleerde commissielid H. C. Cras (1739-1820) was, blijkt uit de mondelinge toelichting op het ontwerp, welke Donker Curtius desverzocht begin-1807 aan de staatsraad van Lodewijk Napoleon gaf, toen deze raad zich zette aan een omwerking van het Ontwerp-Lijfstraffelijk Wetboek-1804. Volgens hem was de codificatiecommissie-1798 ervan uitgegaan, dat het te ontwerpen wetboek een 'Rechts-wetboek' moest zijn, vóór alles geschreven voor 'denkende koppen' (wijsgeren en juristen) en niet voor 'de gemene man'. Daarom moest het een systema juris van wijsgerige regels en beginselen inhouden (vergelijk M. E. Kluit, Cornelis Felix van Maanen tot het herstel der onafhankelijkheid (Historische studies uitgegeven door het Inst. voor Geschiedenis der RU Utrecht, I; Groningen-Djakarta, 1954) 176. 
werp $^{82}$. Naast 'Duitse' auteurs als Kleinschrod ${ }^{83}$, Meister ${ }^{84}$, Gmelin $^{85}$ en anderen dient in dit verband toch wel in de eerste plaats Gaetano Filangieri (1752-1788) te worden genoemd, wiens La Scienza della Legislazione - in Franse vertaling door de ontwerpers veelvuldig als bron van inspiratie en wijsheid werd geraadpleegd ${ }^{86}$. Dit verklaart tevens goeddeels de omstandigheid, dat het Ontwerp-Lijfstraffelijk Wetboek-1804 in sterke mate van 'gejuridiseerde' zedelijke beginselen is doortrokken ${ }^{87}$.

Uit een redactioneel oogpunt ten slotte is het van belang te wijzen op de tamelijk uniforme manier, waarop in de boeken II-IV de afzonderlijke delicten behandeld worden en welke schematisch als volgt kan worden weergegeven:

1. 'Bepaling' van de misdaad (een definitie);

2. 'Kenmerk' van de misdaad (onderscheidend kenmerk);

3. Wijzen waarop de misdaad bedreven kan worden;

4. Wanneer de misdaad voor volbracht gehouden dient te worden;

5. Waardering van de misdaad;

6. Straf, op de misdaad gesteld (eerst in het algemeen, dan in eventuele bijzondere gevallen);

7. Eventueel: de al dan niet strafbaarheid van poging tot de misdaad;

82. Zeer juist heeft Mulder ('Feuerbach', 178) dan ook opgemerkt, dat in vele artikelen van het Ontwerp-Lijfstraffelijk Wetboek-1804 de zinswending 'in het algemeen' voorkomt, welke eveneens ('der Regel nach') frequent figureert in het 'Kleinschrodische Entwurf' (vergelijk nt 58). Kleinschrod wordt door de samenstellers in hun interne commentaren op hun interne voorontwerpen dan ook meermalen aangehaald.

83. Zie noot 58 .

84. Zie noot 54 .

85. Christian Gottlieb Gmelin (1749-1818), Grundsätze der Gesetzgebung über Verbrechen und Strafen (Tübingen, 1785); Abhandlung von den besonderen Rechten der Juden in peinlichen Sachen (Tübingen, 1786).

86. Deze Napolitaanse jurist en pedagoog van Europese vermaardheid deed zijn genoemde, van een moraliserende en rationalistisch-optimistische hervormingsgeest doortrokken hoofdwerk te Napels in de jaren 1780-1785 in zeven delen verschijnen. Het beleefde spoedig vier herdrukken; in de jaren 1786-1791 verscheen een Franse vertaling ervan in zes delen onder de titel La Science de la Législation. Het is vooral de tweede editie van deze Franse vertaling (Parijs, 1791-1799) die Cras, Elout en andere leden van de codificatiecommissie gebruikten. $\mathrm{Zij}$ putten vooral uit Livre troisième (tomes 3-5), getiteld 'Des lois criminelles'. Napoleon I koesterde eveneens een grote bewondering voor Filangieri ('Ce jeune homme, notre maître à tous'), zozeer zelfs dat Mazzacane ('Pénalistes Italiens', 30) spreekt van 'L'heure de Filangieri'. Vergelijk Nouvelle Biographie Générale..., Firmin Didot Frères, ed., XVII (Parijs, 1856) kol. 680-685 (herdruk Kopenhagen, 1965) en uitvoeriger: G. de Ruggiero, Il Pensiero politico meridionale nei secoli XVIII e XIX (Bari, 1922); U. Spirito, Il Pensiero pedagogico di Gaetano Filangieri (Florence, 1924); G. Touchard, 'Un publiciste italien au XVIIIe siècle: Filangieri et la Science de la Législation', Nouvelle Revue Historique de Droit Français et Etranger, XXV (Parijs, 1901) 744-766.

87. Vergelijk Bk I, hfdst. ii, art. 26: 'Hoe meer beweegredenen er te zaam lopen om iemand van eene misdaad te weerhouden, des te snooder is het begaan van die daad'. Art. 62: 'Over het algemeen moet by het waardeeren eener misdaad niet de uitkomst, maar de wil van den dader worden in acht genomen'. 
8. Eventueel: bijkomstige voorschriften (bijvoorbeeld inzake deelneming aan het plegen van de misdaad) ${ }^{88}$.

\section{DE 'NAGESCHIEDENIS' VAN HET ONTWERP-LIJFSTRAFFELIJK WETBOEK 1804}

Heftige reacties wekte het Ontwerp-Lijfstraffelijk Wetboek-1804 bepaald niet op. Afgezien van enkele - merendeels anonieme - tijdschriftartikelen, die in wezen niet meer behelsden dan historisch-strafrechtelijke beschouwingen en zorgvuldig zo neutraal ${ }^{*}$ mogelijk stil en nam men - ook in juridische kringen - in afwachting van het advies van het nationaal gerechtshof en een nadere standpuntbepaling van de koning een voorzichtige terughoudendheid in acht ${ }^{90}$. Dat advies kwam uiteindelijk pas eind oktober 1806 af en werd uitgebracht aan koning Lodewijk Napoleon. De teneur ervan was tamelijk negatief. Afgezien nog daarvan, dat het hof een invoering van dit strafwetboek los van de destijds beraamde codificatie van het burgerlijk recht uiterst bezwaarlijk achtte, was de voornaamste kritiek het te leerstellige karakter van het ontwerp. De commissie had een wetboek met 'stellige wetten' moeten ontwerpen 'en geenszins eene opgave en ontwikkeling van wijsgerige of regtsgeleerde grondbeginselen, bepalingen en verdeelingen, over welke in de scholen der geleerden wordt gehandeld'. Die konden geen 'onderwerp van wetgeving ... uitmaken'. De voornaamste bijkomende algemene bezwaren waren het ontbreken van bepalingen betreffende buitenslands door eigen ingezetenen gepleegde misdrijven en betreffende buitenslands misdreven hebbende en vervolgens naar dit koninkrijk uitgeweken vreemdelingen, het ontbreken van de geldboete onder de straffen en van bepalingen betreffende recidive. Een lijst van artikelsgewijze kritiek was bijgevoegd ${ }^{91}$.

88. Dit 'redactiemodel' werd door de criminele subommissie van de codificatiecommissie-1798 in het najaar van 1800 op initiatief van Donker Curtius aanvaard. Vergelijk Moorman van Kappen, 'Uitwendige Schets', 128.

89. Zo onder meer Algemeene Konst- en Letter-Bode voor het jaar 1805 (Haarlem, 1805) I, 198214 en 215-224. De veronderstelling is geuit, dat de anonieme auteur van deze bijdrage de Amsterdamse hoogleraar H. C. Cras was (vergelijk Regtsgeleerd Magazijn van Prof. Gratama (Groningen, 1809) 136).

90. Hierover beklaagt zich wat later een anoniem scribent in de Schouwburg van in-en uitlandsche Letter- en Huishoudkunde (1808) 360 als volgt: 'En het is te verwonderen, te bejammeren en als gebrek van belangstelling of van vrijmoedigheid, of van beide, te laken, dat, ondanks de van goeder hand gedane uitnoodiging' - namelijk die door de auteur van het in de vorige noot genoemde artikel - 'de Nederlandsche regtsgeleerden achterlijk gebleven zijn met hunne tegenbedenkingen in 't licht te geven. Hoe veel meer wetenschappelijke en staatsburgerlijke gemeengeest leeft er dan in Frankrijk en vooral in Duitschland'! Vermoedelijk was deze auteur de Franeker hoogleraar H. W. Tydeman (1778-1863). Vergelijk Mulder, 'Feuerbach', 184, nt 11.

91. Gedeeltelijk gepubliceerd in De Smidt en Huussen jr, ed., Nederlandse codificatie, I, 549-559. In weerwil van de algemeen luidende titel behelst deze uitgave niet de tekst van het Ontwerp-Lijfstraffelijk Wetboek-1804.(OLW-1804). 
Zonder twijfel was het te uitvoerige, te detaillistische en te leerstellige karakter van het Ontwerp-Lijfstraffelijk Wetboek-1804 het voornaamste punt van kritiek ${ }^{92}$. De overige bezwaren waren immers in beginsel niet zo heel moeilijk te ondervangen geweest. De geleerde Amsterdamse hoogleraar Hendrik Constantijn Cras, die zich als lid van de civiele subcommissie van de codificatiecommissie had beijverd om het Ontwerp-Lijfstraffelijk Wetboek-1801 uitvoerig van commentaar te voorzien, zo uitvoerig zelfs, dat hij in zijn eentje het werk van de criminele subcommissie nog eens overdeed en bepaald niet 'dunnetjes', reageerde scherp, zij het niet publiek, op het advies van het hoog nationaal gerechtshof. Zo heel verwonderlijk was dat niet, want het waren bepaald niet in de laatste plaats zijn geleerde commentaren geweest, die de omwerking en uitbreiding van het Ontwerp-Lïfstraffelijk Wetboek1801 nodig hadden gemaakt. Volgens hem was $\mathrm{mr}$. J. E. Reuvens, de president van het hoog nationaal gerechtshof, de auctor intellectualis geweest van de geleverde kritiek. In zijn anti-kritiek noteert hij ergens geïrriteerd: 'Men bespeurt overal klaar de vittenden geest van R'. Terecht heeft De Smidt mijns inziens verondersteld, dat de inmiddels tot stand gebrachte Code civil (1804) met zijn beknoptheid en heldere stijl op de kritiek van het hoog nationaal gerechtshof van invloed is geweest $^{93}$. Daaruit - evenals trouwens uit de toen vigerende Code pénal van 17911795 - sprak een geheel andere stijl van wetgeving ...

Op last van de koning is de staatsraad in 1807 nog bezig geweest met het beproeven van een omwerking van het Ontwerp-Lijfstraffelijk Wetboek-1804. Naast de officiële notulen zijn vooral de particuliere aantekeningen van C. F. van Maanen, die als 'deskundige' de beraadslagingen bijwoonde, een belangrijke kenbron met betrekking tot dit gezwoeg, omdat zij in tegenstelling tot de officiële notulen niet 'gekuist' en gedepersonifieerd zijn. In welke richting men arbeidde laat zich wel raden: om de haverklap tekent hij bij de successieve artikelen het woord 'uitlaten' $\operatorname{aan}^{94} \ldots$ Toch bleek die omwerking een onbegonnen zaak: de nagestreefde ingrijpende besnoeiingen leidden tot zulke systematische en redactionele problemen, dat men, tot en met het begin van het derde boek gevorderd, tot de conclusie kwam, dat een nieuwe opzet van het geheel noodzakelijk was. Het concipiëren van een nieuw

92. Mulder (Feuerbach, 179) typeerde de hierachter schuil gaande collisie van opvattingen omtrent doel en inhoud van een codificatie zeer juist als 'de tegenstelling tussen het natuurrecht van de achttiende en het legalisme van de negentiende eeuw'.

93. De Smidt, Codificatie-perikelen, 12. Vergelijk de anonieme auteur van 'Eenige berigten nopens de nieuwste Fransche en Hollandsche burgerlijke wetten', Schouwburg van in-en uitlandsche Letter-en Huishoudkunde (1808) 358, nt 1: 'Het Fransch project de code Criminel lezende en met het Bataafsche vergelijkende, moeten wij in het eerste ... ook doorgaans de beknoptheid ... en duidelijkheid bewonderen'. Bedoeld is het van 1804 daterende (voor)ontwerp van de latere Code pénal. 94. Vergelijk Kluit, Van Maanen, 170. Op de eerste van de reeks zittingen, waarop de staatsraad het $O L W-1804$ ter omwerking in behandeling nam, dd. 14 febr. 1807 had koning Lodewijk Napoleon zelf verklaard, dat uit het ontwerp alle 'leerstellige en wijsgerige principes of artikelen' geschrapt moesten worden. 
ontwerp werd de taak van een nieuwe driemanscommissie, bestaande uit - ce qui casse paye - Reuvens als voorzitter, Elout en Van Musschenbroek. Hun ontwerp resulteerde - na nieuwe intensieve besprekingen in de staatsraad, menigmaal onder leiding van de koning zelf ${ }^{95}$ - tot het Crimineel Wetboek voor het koningrijk Holland van 1809 , ons eerste nationale strafwetboek.

Gezien het voorgaande zou men denken, dat er een brede kloof zou gapen tussen het Ontwerp-Lijfstraffelijk Wetboek-1804 en het Crimineel Wetboek van 1809. Daarop is mijns inziens toch wel wat af te dingen. Het is in zoverre juist, dat het wetboek-1809 (394 artikelen) veel beknopter is dan het Ontwerp-Lijfstraffelijk Wetboek-1804 (968 artikelen) en dat die beknoptheid vooral is bereikt door het elimineren van allerlei typisch 'leerstellige' bepalingen. Het wetboek-1809 ademt inderdaad een geheel andere geest, is wars van bespiegelende, theoretiserende en moraliserende elementen. Het - wat men tegenwoordig zou noemen - algemene deel beslaat 61 tamelijk beknopte artikelen ${ }^{96}$, terwijl het Ontwerp-Lijfstraffelijk Wetboek-1804 daarvoor 320 artikelen nodig heeft, die daarenboven goeddeels het karakter dragen van een soort 'instructienormen' voor de rechter, zij het in een niet te verstouwen overmaat.

Het is ook juist voor wat de systematiek, de indeling van beide wetboeken betreft. Het is ten slotte ook nog juist - ofschoon in iets mindere mate - voor wat de inhoud van de algemene gedeelten van beide betreft ${ }^{97}$. Maar wanneer men de bepalingen betreffende de bijzondere delicten, dus die betreffende moord, doodslag, diefstal enz. vergelijkenderwijze beziet, dan stuit men nogal eens op frapperende overeenkomsten, ook al vat het wetboek-1809 vaak in één artikel samen wat het Ontwerp-Lijfstraffelijk Wetboek-1804 in een reeks artikelen decreteert. Naar mijn voorlopige indruk heeft de commissie-Reuvens al met al toch nog heel wat verflenste bloempjes uit het Ontwerp-Lijfstraffelijk Wetboek-1804 geplukt ${ }^{98}$.

95. Vergelijk over deze beraadslagingen Kluit, Van Maanen, 213-219; W. C. van Binsbergen, Algemeen karakter van het Crimineel Wetboek voor het Koningrijk Holland (dissertatie Utrecht; Utrecht, 1949) passim. Uitvoeriger: Précis des Discussions et des Déliberations du Conseil d'Etat sur le Code Criminel, traduit de l'original Hollandais (Amsterdam, 1810) met vele drukfeilen).

96. Formeel beschouwd kent het Crimineel Wetboek geen 'algemeen deel', daar het in dertig doorlopende titels - merendeels onderverdeeld in hoofdstukken - is ingedeeld. Materieel beschouwd vormen echter de drie eerste titels, voorschriften van algemene aard behelzend, wel degelijk een algemeen deel, zij het redactioneel niet als zodanig gepresenteerd. De overige titels hebben telkens op een bepaalde categorie 'misdaden' betrekking, behoudens de beide laatste, die naar tegenwoordige maatstaven een strafprocessueel karakter dragen.

97. De definities van 'misdaad' in het $O L W-1804$ (Bk I, hfdst. i, art. 1) en in het Crim. Wetb. (art. 9) komen evenwel vrijwel overeen. Evenzo komen $O L W-1804$, Bk I, hfdst. i, artt. 7-9 in hoge mate overeen met het - veel geserreerder geredigeerde - art. 12 Crim. Wetb. Vergelijk ook Bk I, hfdst. i, art. 52 OLW-1804 met art. 16 Crim. Wetb. Zo zijn nog heel wat voorbeelden meer te noemen.

98. Vergelijk bijvoorbeeld Bk III, hfdst. i, art. $5 \mathrm{j}^{\circ} 8$ OLW-1804 met art. 97 Crim. Wetb.; Bk III, hfdst. i, artt. 27-28 OLW-1804 met art. 102 Crim. Wetb.; Bk III, hfdst. i, art. 34 OLW-1804 met art. 106 Crim. Wetb.; Bk III, hfdst. i, artt. 43-44 OLW-1804 met art. 113 Crim. Wetb. enz. enz. 
De invloed van het Ontwerp-Lijfstraffelijk Wetboek-1804 op het huidige, van 1881 daterende Wetboek van Strafrecht is te verwaarlozen. De staatscommissie-1870 heeft het bij mijn weten niet geraadpleegd en op het stuk van de zogenaamde 'kleurloze' opzet, één van de zeer weinige elementen die ons Wetboek van Strafrecht ontleende aan het wetboek van 1809, verschilde het Ontwerp-Lijfstraffelijk Wetboek1804 nu juist van het Crimineel Wetboek ${ }^{99}$.

\section{HET BELANG VAN HET ONTWERP-LIJFSTRAFFELIJK WETBOEK-1804}

Waarom dan toch aandacht te besteden aan dit schijnbaar 'verouderde' ontwerp? Vooreerst omdat het juist door zijn 'leerstellige' karakter zo'n uitstekend inzicht geeft in het strafrechtelijk denken van een meer dan middelmatig begaafde groep vaderlandse juristen in die veelbewogen jaren rond het begin van de negentiende eeuw. Met éen been in de tradities van het nog vigerende oud-vaderlandse strafrecht staande, met het andere in de nieuwe ideeënwereld van de Verlichting en met name beïnvloed door nieuwe strafrechtelijke denkbeelden van Italiaans-Duitse herkomst, zagen zij zich, nog juist vóór de Franse wetgeving op civiel- en strafrechtelijk gebied ten onzent overheersend werd, voor de opgave gesteld om zonder precedent hier te lande ${ }^{100}$ een nationaal strafwetboek te ontwerpen voor de nieuwe Bataafse eenheidsstaat, waarin nog steeds verscheidenheid van strafrecht heerste.

Van Rousseau stamt de uitspraak: 'Il faudroit etre Dieu pour donner des loix aux hommes'. Welnu, goden waren zij niet, wel kinderen van hun tijd. Hetgeen zich weerspiegelt niet alleen in hun ontwerp zelf, maar veel meer nog in het overvloedige bronnenmateriaal, dat zij uit het stadium van hun preparatoire werkzaamheden nalieten. Juist die onverbloemde interne stukken wekken hun wetsteksten tot leven, geven inzicht in de achtergronden en motieven daarvan, waarbij naast de meer technisch-juridische aspecten ook allerlei praejuridische factoren aan de dag treden zoals godsdienstige, morele en maatschappelijke opvattingen en inzichten. Juist dat laatste zal, naar ik hoop, de toekomstige bronnenuitgave van het OntwerpLijfstraffelijk Wetboek-1804 voor een ruimere kring historici dan alleen rechtshistorici van belang doen zijn ${ }^{101}$.

99. Vergelijk Bosch, Ontstaan Wetboek van Strafrecht, 82. Vergelijk Bk I, hfdst. i, art. 4 OLW1804 (Boos opzet is hier de wil om te misdoen) en art. 11 Crim. Wetb. (Opzet is de wil om te doen of te laten die daden, welke bij de wet verboden of geboden zijn).

100. De criminele ordonnantiën van 1570 hadden immers voornamelijk op het formele strafrecht en het penitentiaire recht betrekking. Die op de criminele justitie behelsde slechts betrekkelijk weinig bepalingen van materieel strafrecht.

101. Een moderne bronnenuitgave van respectievelijk het subcommissoriale $O L W-1801$ (dat van de criminele subcommissie van de codificatiecommissie 1798) en het $O L W-1804$ is in voorbereiding onder leiding van schrijver dezes. 
Toch speelt naast dit rechts- en cultuurhistorische belang nog een ander belang mee, al zij erkend, dat dat wellicht meer de jurist dan de historicus zal kunnen aanspreken. Het strafrecht is vanouds een uiterst gevoelige en ook niet-juristen verre van onverschillig latende rechtsmaterie, juist omdat strafrechtelijke sancties zo diep ingrijpen in 's mensen vrijheid en existentie. En hoewel het strafrecht van heden in velerlei opzicht verschilt van dat van begin negentiende eeuw, bijvoorbeeld op het stuk van de straffen ${ }^{102}$, zijn er daarnaast toch ook duidelijke overeenkomsten, bestaat er een grote mate van continuiteit. Niet alleen op het stuk van wat men de 'klassieke' delicten zou kunnen noemen (moord, doodslag, diefstal, oplichting, bepaalde zedendelicten en - niet te vergeten - de vandaag de dag weer actuele misdrijven tegen de openbare orde en de algemene veiligheid), maar ook op dat van de algemene beginselen. Het adaequaat formuleren van begrippen als opzet, schuld, poging of uitlokking is nu een even moeilijke opgave als toen. En juist in een tijd, waarin ook het strafrecht aan kritiek onderhevig en sterk in beweging is, kan het uitvoerige en leerstellige Ontwerp-Lijfstraffelijk Wetboek-1804, gepresenteerd in een vorm die de wordingsgeschiedenis van de afzonderlijke bepalingen en alzo alle eraan ten grondslag liggende overwegingen zo compleet mogelijk laat zien, ertoe bijdragen, dat wij ons huidige Wetboek van Strafrecht nóg kritischer gaan bezien ${ }^{103}$. Zo beschouwd kunnen juist die elementen, die het Ontwerp-Lijfstraffelijk Wetboek-1804 destijds deden sneven, de uitvoerigheid en de leerstelligheid ervan, vandaag de dag voor een nadere kritische bezinning op ons positieve en dusdoende op een toekomstig 'beter' strafrecht bevorderlijk zijn.

102. Niet op dat van de rechterlijke straftoemeting. Vergelijk G. E. Mulder, Rechtdoen en rechtspraak (inaug. rede KU Nijmegen; Deventer, 1973) 17: 'Op het punt van straftoemeting zijn wij functioneel gezien weinig verder dan het punt, dat Bentham in 1780 bereikte'.

103. Vergelijk ibidem, 20-11: 'Het strafrecht maakt een kritieke periode door. Ik acht het de taak van de docenten om de huidige ontwikkeling kritisch te begeleiden. Die begeleiding bestaat niet in het stukslaan van bestaande structuren en het bouwen van luchtkastelen die de medemenselijkheid nog meer dan nu in de kou zetten. Het lijkt mij noodzakelijk om alle dingen, niet alleen de bestaande, maar ook de toekomstige te toetsen en zo voorzichtig aan het beter strafrecht te werken, Ons inziens kunnen in het kader van dat toetsingsproces ók de kritische reffecties van Elout, Donker Curtius, Cras en andere leden van de codificatiecommissie op allerlei nog steeds actuele en actueel blijvende vraagstukken van strafrechtelijke aard waardevolle gezichtspunten opleveren'. 